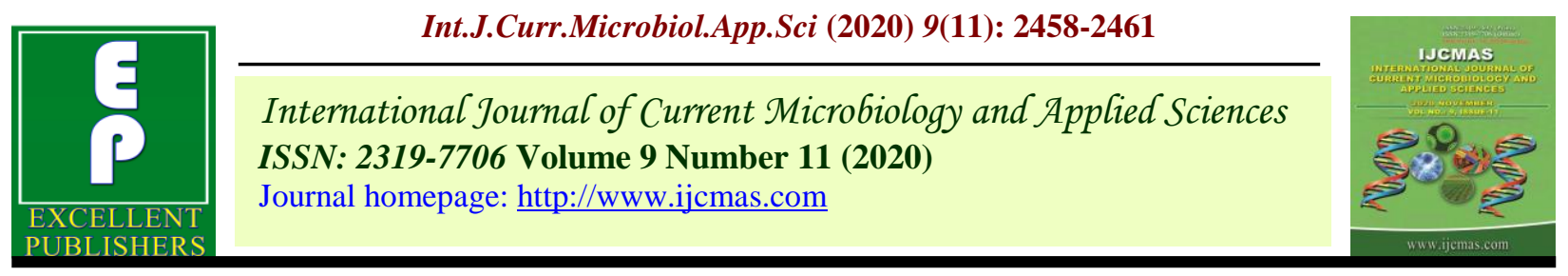

Original Research Article

https://doi.org/10.20546/ijcmas.2020.911.296

\title{
Problems Experienced by Rural Women of Udaipur District in Accessing Rural Credit
}

\author{
Priyanka Rana $^{1 *}$ and Rajshree Upadhyay ${ }^{2}$ \\ ${ }^{1}$ Department of Agriculture Extension, School of Agricultural Sciences, \\ Dabok, JRNRVU, Udaipur, India \\ ${ }^{2}$ Department of EECM, College of Community and Applied Science, MPUAT, Udaipur, India \\ *Corresponding author
}

\begin{abstract}
A B S T R A C T
Keywords

Rural women,

Rural credit

Article Info

Accepted:

17 October 2020

Available Online:

10 November 2020

The present study was undertaken to find out the problem of rural women of Udaipur district about accessing rural credit. The study was conducted in four villages of randomly selected Mavli Panchayat Samiti of Udaipur district of Rajasthan. A sample of 100 rural women was selected randomly for the present study. Personal interview method was used for data collection. Frequency, percentage, means and percent score were used for analysis of the data. Study of problems experienced by rural women in accessing rural credit revealed that the respondents reported the problem of necessity of timely repayment with the mean percent score of 87 , need of collateral security for obtaining personal loan to high extent with the MPS of 83.87, non availability of immediate loan with mean percent score of 82, loan amount was less than required amount (MPS 76.33), non availability of documents (MPS68.33) and long distance of the bank from the village (MPS66).

\section{Introduction}

The role of women is fundamental for the development of all societies. Indian women are vital and productive agent but they are unskilled, restricting them to low-paid occupations and lag behind the men in terms of access to education, health care and jobs. They suffer in all the spheres of social and economic life. Women's role in overall context of human resources development requires that they get their rightful role in society. Their contributions are essential to the development of local and national economies and to the well-being of their

households and communities. Lack of institutional credit has been considered as one of the major constraints to the poor rural women to come out of vicious cycle of poverty. At the government level, attempts like introduction of co-operatives followed by nationalization of commercial banks and opening up regional rural banks were made with a view to reach the institutional credit to the weaker sections, particularly the poor rural women. However all these efforts hardly helped the poor to have better access to institutional credit. The high participation of women in informal credit market has been documented by many third world countries.
\end{abstract}


Rural women often face numerous obstacles, which prevent their access to the official finance system (banks and other official financial institutions and farmer's credit organizations, which give loans to their member). First, rural women have little access to information concerning official savings/ loans institutions. In fact, banks have a considerable communication problem with the rural environment in general, and with women in particular. They have a very limited idea of the nature of institutional savings/loans facilities. The present paper attempts to study problems of rural women about rural credit.

\section{Results and Discussion}

In spite of all the development efforts of government, the access of rural women to institutional sources of credit is limited because of some constraint or problems. Presents study attempts to explore the problems which women faced in accessing rural credit.

Data in Table 1 reveal that most of the respondents $(80 \%)$ reported the problem of necessity of timely repayment as a major problem experienced in accessing rural credit with the mean percent score of 87.The respondents mentioned that timely repayments is not rigidly followed while borrowing money from moneylenders but high interest rate was imposed by them. Majority of the respondents $(67 \%)$ mentioned need of collateral security for obtaining personal loan to high extent with the MPS of 83.87, whereas non availability of immediate loan was reported as problem to high extent by 70 percent of rural women with mean percent score of 82 .

Half of the respondents (50\%) stated that loan amount was less than required amount (MPS 76.33). Non availability of documents and long distance of the bank from the village were the problems faced by rural women with MPS of 68.33 and 66 respectively. Further respondents reported the problem of seeking loan in the name of women with the mean percent score 60.67. Lots of formalities of the banks for seeking loan (MPS 59), lack of information regarding scheme of loan (MPS 54) and lack of information regarding institution providing loan to rural women (48.33MPS) were the other problems revealed by the respondents. Illiteracy (MPS 39.67) and lack of knowledge regarding the loan process (5.33) were also mentioned as problems by the rural women.

Similar findings were revealed by Jain and Parveen (2014) who concluded that majority of the respondents $(87 \%)$ reported problem like sanctioning of loan on the name of women is difficult, (71-76\%) were too many formalities for taking loan from institutional sources, distant locations of banks from village, lack of knowledge about processing of loan from banks, types of various loan and bank facilities which were given to the women members as the members were not actively involved in the bank transaction. Nearly two third of the respondents $(60 \%)$ reported illiteracy and unawareness as a negative factor in getting access to institutional credit. More than half of the respondents $(55 \%)$ mentioned that they have to take loan from the non-institutional sources as small and immediate loan sanctioning is not possible in bank credit and there was unavailability of document like ration card/voter identification card/domicile certificate.

Rathore (2006) also revealed that general problem of rural credit faced by women SHG member were difficulties in sanctioning loan on the name of women, delay in sanctioning distant locations of banks, illiteracy, non availability of document, apathy and non- 
cooperative attitude of bank personnel and complicated procedure of banks.

It can be inferred from the present study that the respondents possessed average knowledge about credit but their utilization was relatively low because they faced some problems also.
They continue to rely on informal credit markets for their economic and social needs because of easy access and flexibility. In order to increase the utilization of rural credit by women, an effort needs to be made to overcome the problems.

Table.1 Distribution of respondents by problems faced in accessing rural credit $n=100$

\begin{tabular}{|c|c|c|c|c|c|c|}
\hline \multirow[t]{2}{*}{ S.No. } & \multirow[t]{2}{*}{ Problems } & \multicolumn{5}{|c|}{ Extent of problems (f/ \%) } \\
\hline & & High & Medium & Low & Nil & MPS \\
\hline 1 & Necessity of timely repayment & 80 & 07 & 07 & 06 & 87 \\
\hline 2 & Need of collateral security for personal loan & 67 & 22 & 06 & 05 & 83.87 \\
\hline 3 & Non availability of immediate loan & 70 & 11 & 14 & 05 & 82 \\
\hline 4 & Loan amount is less than required amount & 51 & 37 & 07 & 06 & 76.33 \\
\hline 5 & Non availability of document & 42 & 31 & 17 & 10 & 68.33 \\
\hline 6 & Distance of bank from the village & 36 & 40 & 13 & 12 & 66 \\
\hline 7 & Problem in seeking loan in name of women & 47 & 15 & 15 & 24 & 60.67 \\
\hline 8 & Lots of formalities of the bank & 28 & 30 & 36 & 07 & 59 \\
\hline 9 & $\begin{array}{l}\text { Lack of information regarding scheme of } \\
\text { loan }\end{array}$ & 15 & 44 & 31 & 11 & 54 \\
\hline 10 & $\begin{array}{l}\text { Lack of information regarding institution } \\
\text { providing loan to rural women. }\end{array}$ & 22 & 23 & 33 & 22 & 48.33 \\
\hline 11 & Illiteracy & 15 & 19 & 36 & 29 & 39.67 \\
\hline 12 & $\begin{array}{l}\text { Lack of knowledge regarding the loan } \\
\text { process }\end{array}$ & 02 & 05 & 03 & 90 & 5.33 \\
\hline
\end{tabular}

Because of the above -mentioned problems of rural women continue to rely on informal credit markets for their economic and social needs because of easy access flexibility of rescheduling and non-requirements of collateral. These advantages in their perception are far outweighing even the exorbitant interest rate of they pay to moneylenders. More ever the formal credit institution does not satisfy the social requirement and other survival needs of poor rural women prefer moneylenders to arranged credit. Credit is powerful development tool but like any instrument, its effectiveness depends on how it is used and above all how well it is known to target groups' i.e. poor rural credit.
In conclusion the general problems of rural credit faced by rural women were loan amount was less than required amount, non availability of documents, and distance location of banks, lots of formalities of the bank, illiteracy and lack of information regarding the loan process.

\section{References}

Lata, P. and Verma, T. 2006. Skillful Employment Generation for the Economic Empowerment of Rural Women. Abstract Volume of National Conference on Range and Scope of Skill Development for Empowerment of Rural Deprived Women, 50: 23-32. 
Moniruzzaman, M.D. 2002. Loan Utilization Patter of Bangladesh Rural Development (BRDB) Women CoGroup: A Comparative Analysis. operative and German Banks (GB) 84.

\section{How to cite this article:}

Priyanka Rana and Rajshree Upadhyay. 2020. Problems Experienced by Rural Women of Udaipur District in Accessing Rural Credit. Int.J.Curr.Microbiol.App.Sci. 9(11): 2458-2461. doi: https://doi.org/10.20546/ijcmas.2020.911.296 